\title{
Osmanlı Hanedan Ailesine Mensup Hanımların Vakıflarında Ramazan Ayına Yönelik Hizmetler*
}

Saadet Maydaer**

Öz

İslam Medeniyeti tarihi boyunca bir çeşit arınma ve maneviyat yükseltme firsatı olarak algılanmış olan Ramazan ayına Osmanlı Devleti'nde de özel bir önem atfedilmiştir. Bu ayda intiyaç sahipleri diğer zamanlardan daha fazla hatılanmış, kimsenin aç ve açıkta kalmamasına özen gösterilmiştir. Camilerde bir araya gelenlerin sayısı artmış, ehil okuyucuların Kur'ân-ı Kerim tilaveti dinlenmiş, temcid gibi bazı özel uygulama ve duaların icrası geleneğimizde yer bulmuştur.

Toplumun her kesimine ve her alanına yönelik icraatları olduğu bilinen vakıfların pek çoğu dini günlere bilhassa da Ramazan ayına mahsus bazı uygulamalara sahiptiler. Bunlardan bir kısmı oruç tutan Müslümanların oruçlarını açmaları için iftariyelik hazırlanmasını sağlamaya çalışırken, bazıları ise Ramazan ayının camilerde coşkulu bir şekilde yaşanmasına katkıda bulunuyorlardı. Büyük ölçekli vakıflar tesis ederek saygın konumlarıyla toplumda öncü rolü üstlenen saraya mensup hanımlar, vakıflarıyla bu ayın maneviyatını arttırmaya ve dinî açıdan daha bereketli geçmesini sağlamaya gayret gösteriyorlardı.

Anahtar Kelimeler: Vakıf, Saraylı Kadınlar, Osmanlı Hanedan Ailesi, Ramazan, Kadın Vakıf kurucuları.

\section{Services in the Month of Ramadan provided by the Waqfs of Ottoman Dynasty Women}

\section{Abstract}

The month of Ramadan, which was perceived as a kind of purification and opportunity to raise spirituality throughout the history of Islamic Civilization, was also given special importance in the Ottoman Empire. In this month, the needy people were remembered more than any other time, and care was taken not to leave anyone hungry or exposed. The number of people gathered in mosques has increased, the recitation of the Holy Quran by competent reciters has been listened, and the performance of some special practices and prayers such as temcid has found a place in our tradition.

Most of the waqfs, which are known to have activities for all segments and aspects of the society, had some practices specific to religious days, especially Ramadan. Some of them were trying to prepare fast-breaking meals for fasting Muslims, while others contributed to the enthusiastic celebration of Ramadan in mosques. The women of the palace, who assumed the leading role in the society with their prestigious positions by establishing large-scale waqfs, were trying to increase the spirituality of this month and make it more religiously fruitful with their waqfs. Keywords: waqf, women of the Ottoman Palace, Ottoman Royal Family, Ramadan, women waqf founders.

* DOI: 10.16971/vakiflar.989101

Makalenin Geliş Tarihi / Received Date: Ağustos 2021 / Agust 2021

Makalenin Kabul Tarihi / Accepted Date: Aralık 2021 / December 2021

** Doç. Dr., Bursa Uludağ Üniversitesi İlahiyat Fakültesi İslam Tarihi Anabilim Dalı, Bursa-TÜRKiYE;

e-posta: msaadet@gmail.com; ORCiD: 0000-0001-8222-7740 


\section{Giriş}

Osmanlı Devleti'nde Müslümanlarca ayrı bir önem atfedilen kandil günleri, Ramazan ayı ve dinî bayramlar oldukça coşkulu yaşanır ve hiç kimsenin bu özel günlerde sıkınt içinde kalmamasına özen gösterilirdi. Toplumun her kesimine hitap eden vakıfların pek çoğunun da dinî günlere mahsus bazı uygulamaları bulunuyordu. Bunların bir kısmı mukabele okutulması gün boyu oruç tutup akşam namazına gelen Müslümanların iftarlarını açmaları için iftariyelik dağıtılması, fakirlere ve öğrencilere iftar verilmesi, Ramazan gecelerinde kandil yakılması, mahya asılması gibi bu ayın maneviyatını arttırmaya ve dinî açıdan daha bereketli geçmesini sağlamaya yönelik uygulamalardır (Ateş, 1982: 77, 78; Yediyıldız, 1982: 3).

Ramazan ayında yetim çocukların giydirilmesi ${ }^{1}$ veya et dağıtılması gibi özellikle fakir ve yetimlere yönelik birtakım faaliyetler de vakıflar eliyle yürütülüyordu. Bunlardan biri olan Ümmü Gülsüm binti Seyyid Ahmet Ağa, Rodosçuk'ta düzenlediği 15 Zilhicce 1204/14 Ağustos 1789 tarihli vakfiyesinde Ramazan ayında her gün 20'şer okka koyun eti satın alınarak vakıf görevlilerine ve fakir Müslümanlara dağıtılması isteğini dile getirmektedir. Aynı vâkıfe, Ramazan ayında fakir ve yetim çocukların bayrama yakın bir zamanda giydirilip hayır dualarının alınmasını da şart koşmuştur (Ateş, 1982: 73-75).

Vakıfların Ramazan ayına özel uygulamaları, saraylı kadınların vakıfları özelinde incelendiğinde ise karşımıza Ramazan ayına yönelik sekiz ayrı hizmet alanı çıkmaktadır. Bunlara geçmeden önce "saraylı kadın" kavramına açıklık getirmek yerinde olacaktır. Bilindiği üzere Osmanlı Devleti’nde padişahların kızlarına "sultan", kız torunlarına ise "hanım sultan" unvanı verilmekteydi (Uzunçarşılı, 1988: 159-166). Fatih dönemine kadar padişahların anne, çocuk ve torunları için kullanılabilmiş olan "sultan" unvanı Fatih Kanunnamesiyle birlikte padişah ve şehzade kızları için resmî unvan haline gelmiştir (Karaca, 1997: 28). ${ }^{2}$ Sultanların has veya paşmaklık adı verilen dirlikleri vardı. Bazıları bir mukataanın gelirinden kendilerine tahsis edilen bir maaş alırken, bir kısmına iltizam veya mâlikâne suretiyle mukataa veriliyordu. Sultanlara bazen hazineden maaş da ödenebiliyordu (Uzunçarşılı, 1988: 165-166). Buna göre 17. yüzyılda saraydaki sultanlar günlük 400 akçeden hesaplanmak üzere ayda 12.000 akçe maaş alıyorlardı (Karaca, 1997: 29). Sultanların gelirlerini idare ve tahsil için voyvoda adı verilen memurlar görevlendiriliyordu (Uzunçarşılı, 1988: 166).

Hanedana aidiyeti ifade eden "sultan" unvanı erkek hanedan mensupları söz konusu olduğunda isimden önce kullanılırken, kadınların isimlerinden sonra getirilmiştir. "Hanım sultan" ise daha ziyade padişah torunlarını ifade etmek üzere kullanılmış olmakla birlikte ilerleyen süreçte hem padişahın hem şehzadelerin kızlarının kızlarına "hanım sultan" denilebilmiştir. Hanım sultanlara belli usuller çerçevesinde maaş tahsis edilebiliyordu. 17. asırda sarayda ikamet eden hanım sultanlar günlük 150 akçeden hesaplanmak üzere ayda 4500 akçe, saray haricinde oturanlar ise günlük 30 akçeden ayda 900 akçe maaş almaktaydılar (Karaca, 1997: 28-29).

Osmanlı padişahlarının eşleri olan hanımlar için de haremdeki düzen dâhilinde kullanılan çeşitli unvanlar karşımıza çıkmaktadır. Bunlar da zaman içinde değişiklik göstermişlerdir. Padişahların eşleri için ilk

1 Örneğin Sultan II. Bayezid'in oğlu Sultan Abdullah'ın azadlısı Kemal Bey'in 5 Muharrem 945/4 Şubat 1538 tarihli vakfiyesinde Bursa'da Nakkaş Ali Mahallesi'nde bir mektep inşa edilmesi istenmiş ve bu mektepte öğrenim görecek 10 yetim çocuğun her biri için her yıl Ramazan Bayramı́nda 60 akçe tutarında giyecek alınması şart koşulmuştur. Vakfiyedeki bu şartın vakıf muhasebe kayıtlarından takip edilebildiği kadarıyla hayata geçirilmiş ve ilerleyen yıllarda da sürdürülmüştür. Yine XVI. yüzyılda Bursa'da yaşayan ve çeşitli vakıflarda bulunan Seyyid Hüseyin Erzincanî kurduğu mektepte öğrenim görecek 15 yetim çocuğun Ramazan ve Kurban bayramlarında dönemin şartlarına uygun şekilde giydirilmesini istemiştir. Ayrıntılı bilgi için bk. Maydaer (2009: 136-141; 2007: 295).

2 Fatih Kanunnamesi'ndeki kullanım için bk. Özcan (1980-81: 51). 
devirlerde "hatun" unvanı kullanılıyordu (Akyıldız, 2001: 94). Orhan Gazi'nin hanımlarına Nilüfer Hatun, Asporça Hatun, Yıldırım Bayezid'in hanımına Devlet Hatun, Fatih'in hanımına Sitti Mükrime Hatun denilmesi bu kullanıma örnek olarak verilebilir. 18. yüzyıla kadar padişah eşlerine hatun dışında "Haseki", "Sultan"4 ve nadiren de "Hanım"5 unvanları verilmekle birlikte genel olarak "kadın/kadın efendi" unvanı kullanılırdı (Uluçay, 2011: 92; Akyıldız, 2001: 95). III. Ahmed'den (Hükümdarlığı 1703-1730) itibaren ise "kadın" ve "kadınefendi" unvanı yaygınlık kazanmaya başladı. Bu dönemden sonra "sultan" kelimesi daha ziyade padişah kızlarını nitelemek için kullanıldı. Oğlu tahta geçen kadınefendiler ise "valide sultan" unvanıyla nitelendiriliyorlardı (Akyıldız, 2001: 95).

Saraydaki kadınların ve cariyelerin konumlarına göre maaşları vardı (Uzunçarşılı, 1988: 149). Hürrem Sultan son zamanlarında günde 2000 akçe maaş alırken, 1575'te tahta çıkan III. Murad, hasekisi Safiye Sultan'a günde 700 akçe maaş bağlatmışt. Bununla birlikte erkek çocuk annesi olan bir padişah eşinin olağan maaşı günde 40 akçe civarındaydı (Peirce, 2002: 171-173). Kadın efendilerin her birine ayrıca kendilerine yetecek miktarda yiyecek, giyecek ve yakacak verilirdi (Uluçay, 2011: 110). Bunların dışında has yani paşmaklık sahibiydiler (Uzunçarşılı, 1988: 149). Osmanlı maliyesinde hanım ve valide sultanlara devlet tarafindan bir arazinin gelirlerinin tahsis edilmesine "paşmaklık" adı veriliyordu (İpşirli, 2007: 186). XVI. yüzyıl sonlarına kadar Osmanlılar'da bu adla ayrılmış topraklar bulunmamaktadır. Zira bu tarihlerden önce de padişahlar valide ve hanım sultanlara çeşitli arazileri mülk veya tımar olarak verebiliyorlardı. Ancak bunun için özel bir adlandırma yoluna gidilmiyordu (ipşirli, 2007: 186-187). Osmanlı toprak düzeninde geliri 100.000 akçeyi aşan tımarlara "has" adı veriliyordu (Üçok, 1944: 536). Hanedana mensup hanımlara tahsis edilen paşmaklıklar da haslar kapsamında değerlendiriliyordu (Orhonlu, Göyünç, 1997: 268). Tanzimattan sonra merkeziyetçi bir sistemle bütün hazineler birleştirilip Maliye Hazinesi idaresine geçirilmiş ve padişahın birkaç çiftliği dışında bütün gelir kaynakları buraya aktarılmıştr. Bu uygulama paşmaklık sahibi olanları da etkilemiş ve onlar da artık hazineden maaş almaya başlamışlardır (Terzi, 2018: 137; Uluçay, 2011: 111)

Padişah ailesinden olan saraylı hanımlar arasında en yüksek gelire sahip olanlar şüphesiz valide sultanlardır. "Valide Sultan" unvanını ilk kullanan Nurbanu Valide Sultan'a günlük 2000 akçe maaş bağlanmıştı (Akyıldız, 2012: 495; Şafak, 2017: 17; Peirce, 2002: 169 ). III. Mehmet'in (1595-1603) validesi Safiye Sultan (ö. 1605) ise günlük 3000 akçeye çıkartılan maaşıyla kendi dönemindeki tüm üst düzey devlet görevlilerinden daha fazla gelire sahip olmuştur. ${ }^{6}$

Valide Sultanların maaşlarının dışında kendilerine tahsis edilen paşmaklıklardan elde ettikleri gelirler de hayli yüksekti. Kösem Sultan'ın yıllık has geliri 20 milyon akçeden fazla iken, Turhan Sultan'ın yıllık has geliri 12 milyon akçe tutarındaydı (Akyıldız, 2012: 495). Kösem Sultan kadar etkin olamayan valide sultanların gelirleri de bir hayli yüksekti. Örneğin Handan Sultan'ın yıllık paşmaklık geliri 1.797.933 akçeyi bulabiliyordu (Peirce, 2002: 285 ). Bu kadar yüksek gelirlere sahip olan bu valide sultanlar ve padişah ailesinin diğer fertleri sahip oldukları maddî gücü genellikle büyük ölçekli vakıflar kurarak değerlendiriyorlardı. $^{7}$

3 Hürrem Haseki Sultan. Haseki terimi belgelerde çok seyrek kullanılmıştır (Uluçay, 2011: 95).

4 Hafsa Sultan, Nurbanu Sultan, Mahfiruz Sultan.

5 Âkile Hanım. (II. Osman'ın hanımı Şeyhülislam Hocazade Esad Efendi'nin Kızı)

6 Bu dönemde üst düzey resmî görevli olan Şeyhülislamın geliri günde 750 akçe, Rumeli ve Anadolu Kazaskerlerinin ise 572 ve 563 akçe civarındaydı (Peirce, 2002: 169).

7 Osmanlı padişah ailesine mensup kadınların yaptırdıkları hayır eserleri ve vakıflara dair örnekler için bk. Singer (2004); Terzi (2018: 187-247); Şafak (2017); Argıt (2014: 171-199); Sabırlı (2012; 2017); Pantık (2014); Zülfikar (1989); Yılmazörnek (2010); Çiçek (2018). 
Osmanlı Hanedan Ailesine Mensup Hanımların Vakıflarında Ramazan Ayına Yönelik Hizmetler

Cami, mektep, medrese, imaret vb. den oluşan büyük külliyeler, köprüler, hatta kaleler, sebiller, hamamlar, çarşılar inşa ettiriyorlar ve bunların hizmetlerinin devamı için önemli gelirler tahsis ediyorlardı. Kurdukları genellikle büyük ölçekli vakıflarda borçlu mahkûmların hapisten kurtarılmasından yetim çocukların giydirilmesine ya da fakir genç kızların çeyizlerinin hazırlanmasına kadar pek çok sosyal hizmetin de görülmesini sağlıyorlardı. Padişahların eşleri, kızları, kız kardeşleri ve anneleri olan bu hanımların kurdukları vakıfların bir kısmında ise İslam dininde önem atfedilen ve halkın muhayyilesinde ayrı bir yer tutan kandil, bayram geceleri ve bilhassa Ramazan ayına dair de birtakım özel şart ve istekler yer alıyordu. Padişah ailesi olan saraylı kadınların vakıflarında yer alan Ramazan ayına yönelik hizmetleri sekiz ayrı başlık altında tasnif etmek mümkündür.

\section{Yemek Pişirilip DağıtıIması}

Bir hayır hizmeti olarak karşımıza çıkan yemek pişirilip dağıtılması talebi Osmanlı'nın ilk vâkıfesi olarak kabul edilen Asporça Hatun'un ${ }^{8}$ Ramazan 723/Eylül 1323 tarihli vakfiyesinde yerini almıştr. ${ }^{9}$ Buna göre yılda iki defa yemek dağıttlacaktır. Bunun için tayin edilen zaman, insanların küçüğüyle büyüğüyle bir arada olup, mutluluklarını paylaştıkları, yiyip içip hoşça vakit geçirdikleri Müslümanların iki bayramı olan Ramazan ve Kurban bayramlarıdır. Yemek pişirilip dağıtlacak kimseler için fazlaca açıklayıcı bir tanımlamaya gidilmemiş ve "fakirler" denilmekle yetinilmiştir. Bayramlarda hemen her evde mükellef sofraların hazırlandığı ve normal zamanlardan daha iyi yemeklerin yenildiği düşünülürse, Asporça Hatun maddi açıdan buna imkân bulamayanların da aynı şekilde leziz yiyeceklere kavuşmasını arzu etmiş olmalıdır.

Asporça Hatun'un bayramlarda başlattğı bu yemek yedirme geleneğini ondan sonra gelen Padişah ailesi mensubu hanımların bir kısmı imaretleriyle sürekli hale getirmişler ve bunlardan bazıları da Ramazan ayında verilen yemeklerin kalitesinin arttrılmasını arzu etmişlerdir. Bunlardan biri olan Yavuz Sultan Selim'in güzelliğiyle meşhur başkadını, Kanuni'nin annesi Hafsa Sultan, Manisa'da cami, imaret, medrese, mektep ve hankâh yaptırmış ve Evasıt-ı Şaban 929/29 Haziran 1523 tarihli vakfiyesinde Ramazan ayına ayrı bir önem atfederek, "Ramazan-ı Şerîf'in her gecesinde ve yalnız dâne ve zerde denilen iki ta'âmın pişirilmesini ve Ramazan-ı Şerîf'in Cum'a ve Kadir gecelerinde mezbûr iki ta'âmla berâber zirbaç ta'âmının dahi pişirilmesini ve mezbûr leyâlîi-i şerîfede koyun etinin mezbûr vilâyetin okkası ile on altı okka olmasını" istemiştir. ${ }^{10}$

Özel günlerin ve normal günlerde özel kişilerin yiyeceği olarak İstanbul'dan Manisa'ya, Bosna'dan Kudüs'e tüm Osmanlı topraklarındaki imaretlerde ikram edilen dane yemeği, 15. yy. Osmanlı mutfağını bize anlatan Muhammed b Mahmud Şirvani'nin ifade ettiğine göre aslında dane-i pirinç, dane-i kabûniyye ve dane-i nergisiyye olmak üzere üç farklı versiyonu bulunan bir yemektir (Şirvanî, 2005: 286). Dane-i pirinç kavrulmuş et, kuyruk yağı ve çeşitli baharatlarla yapılan bir tür pirinç pilavı ${ }^{11}$ iken, dane-i kabûniyye; taze koyun eti, kimyon, tarçın, karabiber, soğan, pirinç, nohut ve kayısı ile hazırlanan bir tür pirinçli, baharatı et yemeği idi. Dane-i nergisiyye ise koyun eti, havuç, nohut ve soğan kavurmasının üzerine pirinç ilavesiyle yapılan bir yemektir (Şirvanî, 2005: 286, 124, 231).

8 Asporça Hatun Orhan Gazi'nin Rum asıllı eşidir. Kayınpederi Osman Gazi’nin kendisine hediye ettiği arazileri Ramazan 723/ tarihli vakfiyesinde bağışladığını bildirmiştir.

9 Asporça Hatun Vakfiyesi, Fatih Millet Kütüphanesi, Ali Emirî, Arapça Yazmalar, nu: 4469; Vakıflar Genel Müdürlüğü, D. 590, 207/181. Vakfiyenin tıpkıbasımı ve tercümesi için bk. Sevim-Öcalan (2010: 15-23); Öcalan-Sevim-Yavaş (2013: 24-29).

10 VGMA, D. 576, 31/15.

11 O günlerde pirinç büyük oranda ithal edilen bir ürün olduğundan, ancak büyük kentlerde ve Anadolu'da üretilebildiği nadir bölgelerde ulaşılabilen bir tahıldı. Pirinç Osmanlı kent kültüründe yeni sayılabilecek bir yiyecek türüydü. Osmanlı toplumunda alışıldık olan ve herkesin rahatlıkla pişirebildiği ve yiyebildiği pirinç değil, bulgur aşı/pilavıydı (Yerasimos, 2011: 140). 
Hafsa Sultan hem besleyiciliği yüksek hem de lezzetli ve biraz da masraflı bu yemeklerin Ramazan boyunca her gün yapılmasını isteyerek, oruç tutan Müslümanların iftarlarını lezzetli ve doyurucu bir yemekle açmalarını sağlamakta ve böylece onların hayır duasını almayı ummaktadır. Ramazan ayı içindeki Cuma ve Kadir gecelerine ise daha fazla hürmet göstermekte ve bunun bir nişanesi olarak sözü edilen gecelerde dane ve zerdeye ilaveten zirbaç adlı yemeğin de pişirilmesini arzu etmektedir. Zirbaç, Şirvani'nin tarifine göre yine koyun eti, bal, tarçın, nohut, badem ve safranla yapılan bir yemekti (Şirvanî, 2005: 355).

Kanuni'nin annesinin ardından eşi Hürrem Sultan da imaretler inşa ettirmiş ve ücretsiz yemek dağıtımı sağlamıştır. Hürrem Sultan'ın İstanbul'daki Haseki İmareti için düzenlettiği vakfiyesinde Ramazan ve diğer özel günlerde "dane-i pirinç" verilmesi istenmekte ve içine konulacak malzemeler ayrıntılı bir şekilde dile getirilmektedir. ${ }^{12}$

Zirbaç imaretlerde daneye göre daha az sıklıkta pişirilirdi. Hafsa Sultan zırbaçın sadece Ramazan ayında Cuma günleri ve bir de Kadir Gecesi ikram edilmesini isterken Hürrem Sultan, Haseki İmareti'nde Ramazan'da danenin yanında dönüşümlü olarak pişirilmesini şart koşmuştur. Buna göre dane Ramazan boyunca Haseki İmareti'nde her gün yapılacak, yanında birinci gün zerde, ikinci gün, zirbaç, üçüncü gün ekşili aş verilecek ve bu durum münavebeli bir şekilde sürdürülecektir. ${ }^{13}$ Hürrem Sultan'ın Kudüs ve Medine'deki imaretlerinde ise zirbaç yemeğinden bahsedilmemekte ve Ramazan boyunca her akşam dane ve zerde ikram edilmesi istenmektedir (Kartal, 2012: 321). ${ }^{14}$

Mihrimah Sultan Üsküdar'daki imaretinde Ramazan'da her gece dane, zerde, zirbaç ve çorba-i turş yani ekşili aş/çorba verilmesini arzu etmektedir (Zülfikar, 1989: 56). 1582'de Üsküdar'da Atik Valide Sultan Külliyesi'ni tesis eden Nurbanu Valide Sultan da Ramazan'da dane, zerde ve zirbacın her gün çıkarılmasını arzu etmiştir (Pantık, 2014: 111). Mihrişah Sultan ve Gülnuş Emetullah Sultan'ın Ramazan'daki iftar menüsü ise dane ve zerdeden oluşmaktadır. ${ }^{15}$

Görüldüğü üzere padişah ailesi olan hanımların kurdukları imaretlerde Ramazan ayındaki iftar menüleri tıpkı diğer büyük imaretlerdeki gibi dane ile zerde ve zaman zaman da zirbaçtan oluşmakta, bu hususta Kanuni'nin çok sevdiği eşi Hürrem Sultan'ın Haseki imaretiyle, sevgili kızı Mihrimah Sultan'ın Üsküdar'daki imaretleri menüye ekşili aş ilave ederek ayrılmaktadırlar. Hürrem Sultan vakfiyesinde ekşili aş için alınması istenen malzemeler; kara üzüm, kırmızı üzüm, erik, zerdali, incir, nane ve pestil olarak sıralanmıştır. Mihrimah Sultan imaretindeki ekşili aş/çorba-ı turşta ise bunlara pirinç, nohut ve bademin de ilave edildiği görülür (Zülfikar, 1989: 56).

İmaretlerde sıradan günlerde tatı ikramı geleneği bulunmuyordu. Oysa özel günlerde ve Ramazan boyunca zerde adı verilen safran, pirinç, su ve balla pişirilen bir tatlı tüm misafirlere ikram edilirdi. ${ }^{16}$ Böylece Ramazan ayında tüm gün aç kalarak oruç ibadetini yerine getiren insanların gün boyunca kaybettikleri kaloriyi hem lezzetli hem de besleyici bir menüyü tüketerek geri kazanmaları sağlanıyordu.

12 Vakfiyede ifade edildiği şekliyle "dane-i pirinç" pirinç, tereyağı, nohut ve soğandan yapılan bir pilavdır. (VGMA, 608/2, 222, 177). Hürrem Sultan'ın beş asıl vakfiyesi vardır. Bunlardan Recep 947/Kasım 1552 ve Muharrem 958/Ocak 1551 tarihlileri İstanbul'daki Haseki Sultan Külliyesi'ne ait olup, diğer üçü Kudüs'teki külliyesine dairdir. Hürrem Sultan'ın vakfiyeleri hakkında ayrıntılı bilgi için bkz. Kartal, 2012: 118-119.

13 VGMA, D. 608/2, 222, 177. (958/1551 tarihli Haseki Vakfiyesi) Vakfiyenin Türkçe tercümesi için bk. Kartal (2012: 529-548).

14 VGMA, D. 608/2, 235, 178.

15 VGMA, D. 608/2, 235, 178. VGMA, D. 1452, K. 177, s. 131a-132a. Mihrişah Sultan Vakfiyesi ve Zeylleri için bk. Kala-Akarçeşme (2019). VGMA, D. 1640, 27/6, s. 33. Gülnuş Emetullah Sultan'ın ilgili vakfiyesinin aslı için bk. Akbulut (2003: 167-176). Aynı vakfiyenin transkripsiyonu için bk. Özgüleş (2013: 558-574).

16 Zerde ile ilgili en eski kayıt 15. yüzyılda Fatih İmareti'ne dair bir kayıtta geçmektedir (Ünsal, 2011: 265). 


\section{Soğuk Su ve Bal Şerbeti DağıtıIması}

$\mathrm{Hz}$. Peygamber'in sadaka-i cariye kapsamında su ihtiyacının giderilmesini sık sık teşvik etmiş olmasının da sâikiyle Müslümanlar İslam medeniyeti tarihi boyunca su dağıtımı ve suyolları yapımı gibi suyla ilgili vakıflarda bulunmaya büyük önem vermişlerdir. Hz. Peygamber'in Medine'ye hicretin ardından Hz. Osman'dan satın alarak ücretsiz su dağıtmasını istediği Rûme Kuyusu ile başlayan bu gelenek "sebil" ve "çeşme" lerde oldukça estetik ve fonksiyonel hale bürünmüştür. Mihrimah Sultan'ın Rüstem Paşa Türbesi yakınlarındaki çeşmesinde de bu geleneğin bir devamı niteliğinde gelip geçen susuzlara su dağıtılması istenmiş, yazın sıcak günlerde ise birer yük kar, sıcağın en şiddetli olduğu Temmuz ve Ağustos aylarında ise her gün 2,5 yük karla dağıtılan suyun soğutulması arzu edilmiştir. Şüphesiz su dağıtım hizmeti Ramazan ayında da devam edecek, ancak gündüzleri insanlar oruçlu olduğu için bu hizmet geceye tahvil edilecektir. İşte Ramazan ayı yaz sıcaklarına denk geldiğinde her gece dağıtılan su birer denk karla soğutularak soğuk su içmek isteyen Müslümanlara dağıtlacaktı (Zülfikar, 1989: 53). Böylece kar ve buzun elde edilmesinin oldukça zahmetli ve pahalı olduğu bir dönemde adeta lüks kabul edilen soğuk suyun her isteyene ücretsiz bir şekilde verilmesiyle tüm gün sıcakta oruç tutan Müslümanların serinletilmesine çalışılmıştı. ${ }^{17}$

Ramazan ayında sudan başka içeceklerin de dağıtımının yapılabildiği görülmektedir. Hatice Turhan Sultan bu hususta farklı bir uygulamaya imza atarak, Ramazan gecelerinde Eminönü'nde inşa ettirdiği Yeni Camii'nin üç kapısında teravih namazından çıkan Müslümanlara ikişer şerbetçinin bal şerbeti dağıtmasını arzu etmiştir. Bu şerbetin yapılabilmesi için bedeli ne olursa olsun Atina balı satın alınmalı ve her gece 33'er vukiyyesinden yapılan şerbet dağıtılmalıdır. Mihrimah Sultan'daki incelik Turhan Sultan'da da görülmekte ve eğer Ramazan yaz aylarına denk gelmişse sebilhaneye tayin olunan kar cami kapılarında dağıttlan şerbete konularak, teravihte enerji harcamış Müslümanların serin bir şerbetle içlerinin serinletilmesine çalışılmaktadır.

\section{3. iftariyelik Verilmesi}

Ramazan ayını diğer aylardan farklı kılan en temel özelliği şüphesiz bu ayda Müslümanların oruç tutmasıdır. Tüm günü oruçlu olarak geçiren Müslümanlar akşam ezanı okunduğunda bir lokma yiyecek veya suyla orucunu açacaktır. Kültürümüzde "iftariyelik" adı verilen ve orucu açmak için tüketilen yiyecekler özellikle iftar vakti evin dışında olanlar açısından önem arz etmektedir. Bu nedenle daha ziyade akşam namazını kılmak üzere camiye gelenlere veya tekkelerde meskûn dervişlere yönelik olmak üzere iftariyelik alınması için vakıfta bulunulduğu görülmektedir. ${ }^{18}$

Pertevniyal Valide Sultan ${ }^{19}$ da kurduğu vakıflarında iftariyelik dağıtımı için hatırı sayılır bir bütçe ayırmıştır. Vakfiyelerinde İstanbul'daki altı farklı tekkede Ramazan'da iftariyelik alınıp dağıtılması için yıllık toplam 6500 kuruşluk bir harcama yapılması öngörülmüştür. Buna göre Fındıklı'daki Keşfi Cafer Tekkesi'ne derviş ve fakirlere dağıtılmak üzere 1000 kuruş, Eyüp’te bulunan Kaşgarî Abdullah Efendi Dergâhı'na 1000 kuruş, Kadırga Limanı civarında yer alan Şehid Mehmed Paşa Dergâhı'na 500 kuruş, Unkapanı Kapısı içinde Balmumcu Ahmed Efendi Zaviyesi'ne 500 kuruş, Galata'da Kasımpaşa Mevlevihanesi'ne 200 kuruş, Yahya Efendi Tekkesi'ne ise önce $1272 / 1855$ 'de düzenlenen vakfiyede 600 kuruş ayrılması talebi dile getirilmiş, 1280/1863'de ise buraya 2400 kuruş ilave edilmesi istenmiştir (Yıldız, 2016: 39, 47, 48,

17 VGMA, D. 744, 112/29.

18 Bunlardan biri olan Sıtkı Efendizade Ahmet Raşit Efendi, Ramazan ayında İstanbul'da Fatih Sultan Mehmed Camii'ne akşam namazı kılmak üzere gelen Müslümanlardan her birine birer hurma verilmesini arzu ettiğini 19 Şaban $1247 / 11$ Ocak 1831 tarihli vakfiyesinde dile getirmiştir (Ateş, 1982: 78).

19 II. Mahmud'un II. İkbali iken Abdülaziz'i doğurmuştur. Ayrıntılı bilgi için bk. Uluçay (2001: 124-126). 
49, 52, 53; Seyhun, 2019: 57, 58). Vakfa ilişkin muhasebe kayıtları incelendiğinde Pertevniyal Sultan'ın vakfiyelerinde öngörülen bu iftariyelik ücretlerinin uygulamaya geçirildiği görülmektedir (Demir, 2019: $35,53,54,55,87,102,103,118,119,120)$.

\section{Camilerde Ramazan'ın Manevî Hazzını Arttırmaya Yönelik Uygulamalar}

İslam medeniyetinde camilerde Kur'ân-ı Kerim okunmasına yönelik vakıfların varlığı ilk dönemlerden itibaren bilinmektedir. ${ }^{20}$ Osmanlı toplumunda da sâir zamanlarda camide Kur'ân okunması için çok sayıda vakıf kurulmuştur. Ramazan ayında ise hem diğer zamanlara oranla daha fazla Kur'ân okunmakta hem de okuyanların mahareti daha bir ön plana çıkmaktadır. Padişah ailesi mensubu hanımlar da tesis ettikleri vakıflarında Ramazan ayında Kur'ân-ı Kerim okunmasıyla ilgili özel bazı isteklerde bulunabilmişlerdir. Bunlardan biri olan Mihrişah Sultan Ramazan'da camilerin güzel sesli kâri'lerin okudukları Kur'ân-ı Kerim'le şenlenmesini de arzu etmektedir. Bunun için teravih arasında aşır-hanların aşır, ìlas-hanların îhlas Sûresi okumalarını talep etmektedir. Ayrıca Ramazan'da sahurdan sonra minarelerden okunan bir tür dua olan temcidin ${ }^{21}$ okunması için de bir temcidhan görevlendirilmesini istemektedir. ${ }^{22}$ Temcid okunması zamanla önemli bir gelenek halini almış, hatta temcidin okunması esnasında insanlar minarelerin altında toplanıp temcid hakkında kendi aralarında yorum ve değerlendirmelerde bulunmaya başlamışlardı (Çiçek, 2018: 85).

\section{Kandil ve Mahyalarla Camilerin Aydınlatılması}

Bir sıvı yağ haznesinin içinde bulunan fitilin yanmasıyla elde edilen aydınlatma aleti olarak tasvir edilen kandil eski çağlardan itibaren kullanıımıştır (Bozkurt, 2001: 299). Mescidlerde aydınlatma amacıyla kandil kullanımının geçmişi ise $\mathrm{Hz}$. Peygamber dönemine kadar uzanmaktadır ve ilk defa Temim ed-Dari'nin eliyle Mescid-i Nebevî kandille aydınlatılmış ve bu durum Peygamber efendimizin övgüsüne mazhar olmuştur (ibnü'l-Esir, 1994: 428; Köksal, 1981: 130). Dolayısıyla onun izinden giderek mescidleri aydınlatmak isteyen Müslümanlar İslam tarihi boyunca var olmuşlar ve kurdukları vakıflarla bunu kurumsallaştırmışlardır.

Osmanlı Devleti'nde gelenek minarelerdeki kandillerin Ramazan geceleri yakılıp, bayram gecesi söndürülmesiydi. III. Ahmed'in emriyle bayram geceleri de kandiller yakılmaya devam edildi (Bezci, 2018: 103). Kandiller Ramazan hilalinin görüldüğünün ilanı için de kullanılabiliyorlardı. Ramazan'ın ilanı Süleymaniye Camii'nin kandilcilerine mahyacıbaşı tarafindan haber verilir, diğer minareler de oradan görerek kandillerini yakarlardı. Bekçiler davullarla mahalle aralarında dolaşarak ertesi günü sahura kalkılacağını herkese duyururlardı. Ramazan yaklaşınca camilerin kayyımları kandilleri temizler, yakılmaya hazır hale getirirlerdi. Küçük ibriklere konan zeytinyağı azar azar kandillere dökülür ve yakılabilmeleri için de meşale kullanılırdı (Bezci, 2018: s. 103, 104).

İslam dünyasında kandil kullanımının Mescid-i Nebevi'de uygulanmaya başlamasının ardından yaygınlaştğı görülmektedir. Hz. Ömer halifeliği esnasında Mescid-i Haram'ın sahasını genişletmiş ve ihata duvarı üzerine kandiller koydurmuştur. Diğer mescidlerin de aynı şekilde kandillerle aydınlatılmasını

20 Emevi Halifesi Velid b. Abdülmelik tarafindan inşa ettirilen Şam’daki Emeviyye Camii ilerleyen yıllarda hem ilim hem de kıraat meclisleri açısından verimli bir ortam sağlamışt. Camide biri sabah diğeri ikindi namazından sonra olmak üzere iki büyük kıraat halkası kuruluyordu. Sabah sub' denilen kıraat halkasında Kur'ân'ın yedide biri okunur ve haftada bir hatim indirilirdi. İkindi namazından sonra ise daha ziyade çocukların ve henüz iyi Kur'ân okuyamayanların katıldığı ve Kevser suresinden Kur'ân'ın sonuna kadar okunduğu Kevseriyye denilen bir halka oluşturulurdu. Camide Kur'ân okuyan 600 civarındaki cüzhanın vazifelerini yerine getirip getirmedikleri vakıf görevlilerince kontrol edilirdi (Özel, 1995: 111).

21 Temcid; sabaha karşı minarelerde belli makamlarda okunan dua.

22 VGMA, D. 1452, K. 177, s. 144b; VGMA, D. 1453, K. 176, s. 24 a. 
istemiştir. Ramazan ayında buraları dolaşan Hz. Ali, Hz. Ömer için "Mescidlerimizi aydınlattı̆ı gibi Allah da onun kabrini aydınlatsın" diye duada bulunmuştur (Bozkurt, 2001: 300). İşte belki de bu duaya mazhar olabilmek için İslam tarihi boyunca mescidlerin aydınlatılmasına Müslümanların büyük bir gayret gösterdiklerini söyleyebiliriz. Bu minvalden olmak üzere sahip oldukları mal varlıklarını vakıflar tesis ederek değerlendiren ve sevap kazanabilme ümidinde olan padişah ailesinin fertleri olan hanımlar da kurdukları vakıflarda çoğunlukla kendilerinin inşa ettirdikleri camilerin kandillerle aydınlatılmasını istemişlerdir. Bunlardan ilki de Osmanlı Devleti'nin bilinen ilk vâkıfesi diyebileceğimiz Asporça Hatun'dur. $\mathrm{O}$, üç aylardaki mübarek gecelerde balmumundan kandillerin yakılmasını isteyerek diğer hanımların da bu hususta öncüsü olmuştur. ${ }^{23}$ Ondan sonraki saray mensubu hanımlar, kandillerle cami ve diğer inşa ettikleri binalarda aydınlatma yapılması için belli bir meblağı ayırmakta ve bu amaçla revgan-ı zeyt yani zeytinyağı alınması talebini dile getirmektedirler. Teravihlerin kılındığı ve şüphesiz gecelerin diğer zamanlara göre çok daha coşkulu yaşandığı Ramazan ayında camilerde yakılan kandillerin sayısı genellikle arttırılmaktadır. Örneğin Kanuni'nin çok sevdiği kızı Mihrimah Sultan, Ramazan ayı boyunca her gece Üsküdar'da inşa ettirdiği camisinin minaresi için 6 vukiyye, Edirne'deki camisi içinse 3 vukiyye revgan-ı zeyt alınmasını istemektedir (Zülfikar, 1989: 45). III. Murad'ın kızı Ayşe Sultan da 1011/1603 tarihli vakfiyesinde Ramazan ayında İstanbul Kasımpaşa'daki Şeyh Emin Efendi Camii'nin Minaresinde mütevellinin görüşü dahilinde "âdet-i marûfe ve kâide-i me'lûfe" ile kandiller yakılmasını arzu ettiğini dile getirmektedir. Bunun için gerekli kandil, revgan ve onu yakacak kişiye yeterli miktarda para verilsin." şeklinde kandil yakılması isteğini dile getirmektedir. ${ }^{24}$ I. İbrahim'in hasekisi ve IV. Mehmed'in annesi olan Hatice Turhan Sultan ise, 1663 tarihli vakfiyesinde gerek Eminönü'nde inşasını tamamlattğı Yeni Camii, gerekse Çanakkale'de yaptırdığı kalelerin içindeki camilerde ve minarelerinde özellikle Ramazan-ı Şerifde yeterli miktarda kandil yakıımasını, bunun için gerekli olan revgan-ı zeyt ile uygun miktarda zincir ve kazayağı alınmasını istemektedir. Ramazan'da minarelerin kandillerini yakmak üzere istihdam olunan kimselere ise yılda 4000 akçe ücret ödenmesini kararlaştırmıştr. ${ }^{25}$

Avcı Mehmed diye bilinen padişah IV. Mehmed'in hanımı ve II. Mustafa'nın annesi olup 20 yıl valide sultanlık yapan Gülnuş Emetullah Sultan da camileri aydınlatanlar kervanına katılmış ve Ramazan'da ve diğer mübarek gecelerde camideki $\operatorname{sirac}^{26}$ tabaklarının arttırılmasını ve kubbenin etrafinda kandiller yakılmasını ve bunları yakmakla görevli kişiye de günde 5 akçe ödenmesini istemiştir. ${ }^{27}$

III. Selim'in annesi olarak valide sultanlık yapan hayırseverliğiyle meşhur Mihrişah Sultan bu hususta kendinden önceki valide sultanların izinden gitmiş ve 1209/1795 tarihli vakfiyesinde Ramazan'da kandillerin yakılması için sair günlerden daha fazla revgan-ı zeyt alınması talebini dile getirmiştir. ${ }^{28}$

Kandiller camilerin aydınlatımasında fonksiyonel bir işleve sahiptir ve dolayısıyla Ramazan'da özellikle teravih nedeniyle artan aydınlatma ihtiyacını karşılamaktadır. İki minare arasına gerilen iplerin üzerindeki kandillerin çeşitli şekillerde konumlandırılmasıyla elde edilen resim ve yazı figürlerinden oluşan mahya ise aydınlatma ihtiyacının karşılanmasının yanı sıra görsel bir şölene dönüşmektedir. Bu haliyle bir Osmanlı icadı olan ve seyyahların ifadelerine göre 16. yüzyıldan itibaren varlığından haberdar olunan ancak kesin olarak ne zamandan beri kullanıldığı bilinmeyen mahya adeta Ramazan'ın bir sembolü olarak algılanmaktadır (Bozkurt, 2003: 396-398).

23 VGMA, D. 590, 207/181.

24 VGMA, D. 1431, K. 98, 1/1.

25 VGMA, D. 744, 112/29.

26 Sirac aydınlatma amacıyla kullanılır (Şemseddin Sami, 1996: 713).

27 VGMA, D. 1640, 27/6, s. 39.

28 VGMA, D. 1452, K. 177, s. 151a, 151b. 
1722 'den itibaren yaygınlaşmaya başlayan mahyaların İstanbul'un iplerin gerilebilmesi için iki minareye duyulan ihtiyacın da etkisiyle özellikle selatîn camilerinde kurulduğu bilinmektedir. (Bozkurt, 2003: 397). Padişah ailesine mensup hanımlardan bu uygulamaya yönelik vakıf kuran Pertevniyal Valide Sultan, 1289/1872 tarihli vakfiyesinde sanatında mahir, kâmil bir üstadın mahyacı olarak tayin edilmesini arzu etmiş̧tir. Ücreti ise aylık 20, yıllık 500 kuruş olacaktır (Yıldız, 2016: 65, 68; Seyhun, 2019: 36).

\section{6. İksa/Giydirme}

Ramazan'da fakirlerin, yetimlerin giydirilmesi padişah ailesine mensup hanımların bir diğer hayır hizmeti olarak kayıtlara geçmiştir. Hürrem Sultan 1551 tarihli Haseki Vakfiyesi'nde İstanbul'da vakfettiği mektepte okuyan, Kur’ân-ı Kerim öğrenen 10 öksüz çocuğun Ramazan Bayramı'nda giydirilmesini istemektedir. Bu yapılırken halk arasında adet olduğu üzere çocuklara uygun elbiselerin seçilmesini arzu etmekte, ayrınt vermemektedir. ${ }^{29}$

Hatice Turhan Sultan ise yine mektepde Kur'ân okuyan çocukların giydirilmesi yönünde vakıfta bulunmakta ve bunun için alınacakların neler olduğunu da tafsilatlı bir şekilde dile getirmektedir. Buna göre her biri için birer kapama, don, gömlek, takke, kuşak, mest ve pabuç alınmalıdır. Turhan Sultan bu giyeceklerin sadece mektep çocuklarına değil, onları okutan hoca, halife ve mekteple ilgilenen kayyıma da alınmasını istemektedir. Hepsi için ayırdığı bütçe ise toplam 25.000 akçedir. ${ }^{30}$

Benzer bir uygulama Pertevniyal Valide Sultan vakfiyesinde de görülür. Pertevniyal Valide Sultan, eşi II. Mahmud'a izafeten "Mahmudiye Mektebi” ismiyle alt katını sıbyan mektebi, üst katını ise rüştiye olarak tasarladığı eğitim kurumunda ${ }^{31}$ öğrenim gören tüm öğrencilere Ramazan öncesinde elbise almaları için her birine 150 kuruş olmak üzere toplam 22.500 kuruş ayrılmasını istemiştir (Yıldız, 2016: 70). ${ }^{32}$

\section{Miskinlere (Cüzzamlılara) Yardım}

İnsanlığın belli dönemlerde uğraşmak zorunda kaldıkları salgın hastalıklardan biri de cüzzam olmuştur. Tüm dünyada yüzlerce yıl tesirini gösteren ve bulaşıcı olduğu için hemen tüm toplumlarda tecrit edilmeye çalışılan cüzzamlılara ${ }^{33}$ karşı Osmanlılar da benzer bir tutumu biraz daha müşfik bir tarzda sergilemişlerdir. Topluma hastalığı yaymalarını önlemek amacıyla şehrin yerleşim yerlerinden uzak mekânlarda kurulan ve "Miskinler Tekkesi" adı verilen yerlerde barınmaları sağlanmıştr. Osmanlı Devleti'nde ilk “Miskinhane" II. Murad (1421-1451) döneminde Edirne'de açılmıştır (Dikeçligil, 2015: 77). İstanbul'da cüzzam hastalarına yönelik “Miskinler Tekkesi'ni” ise 1514'de Yavuz Sultan Selim Üsküdar'da inşa ettirmiştir (Yıldırım, 2005: 186).

O dönemde cüzzam için bir tedavi uygulanamadığından hastalandığı tespit edilen kişi ölü kabul edilip, malı miras sayılır ve tekkeye getirilirdi (Yıldırım, 2005: 185, 186). Buradaki insanlar için halk ve vakıflar çeşitli yardımlarda bulunuyorlardı. Anlaşıldığı kadarıyla Hatice Turhan Sultan da onları unutmamış ve Ramazan ayında bazı ihtiyaçlarının karşılanmasını talep etmişti. Zira vakfiyesinde her yıl Ramazan ayı başlangııında Üsküdar'da kendilerine tahsis edilmiş mahalde kalan miskinlere pirinç, revgan ve odun alınması için 12.000 akçe sarfedilmesini arzu ettiğini dile getirmiştir. ${ }^{34}$

9 VGMA, 608/2, 222, 177

30 VGMA, D. 744, 112/29.

31 Günümüzde Pertevniyal Lisesi olarak eğitim vermektedir. Bkz. Seyhun, 2019: 116; Çiçek, 2018: 56.

32 Bayramlarda ödenen elbise parası ve yakacak yardım bedellerinin 1930'lara kadar ödendiği bildirilmektedir (Çiçek, 2018: 57).

33 Avrupa'da yaklaşık 700 yıl etkili olduğu bilinen cüzzama karşı farklı kültürlerde geliştirilen tutumlar için bk. Nikiforuk (2013: 65).

34 VGMA, D. 744, 112/29. 


\section{Baklava Akçesi}

Sahip oldukları mal varlıklarını vakfeden insanlar vakıf hizmetlerinin düzgün bir şekilde yürütebilmesini bir parça da o vakfin personeline borçludurlar. Bunun farkında olan ve vakıf personelini motive etmek isteyen bazı vâkıfeler özel geceler, bayram ve Ramazan gibi yılın belli dönemlerinde onlara verdikleri bazı hediye veya ikramiyelerle gönüllerini hoş tutmaya çalışmışlardır. Bunlardan biri olan Kösem Mahpeyker Sultan ${ }^{35}$ Ramazanlarda vakıf görevlilerine "Baklava akçesi" adı altında bir çeşit ikramiye verilmesini öngörmüştür. Buna göre vakıf personelinin bir kısmı 200'er, diğer bir kısmı ise 100’er akçe baklava akçesi olarak alacaklardır. İkiyüzer akçe alacak görevliler; İmam, odalarda kalan talebeye talim yaptıran muhaddis, şeyhü'l-kurra olarak belirlenmiştir. Yüzer akçe alacaklar ise; vaiz, hatip, devirhanlar, ser-mahfel, naathan, muarrife, mektep hocası, halifesi, 4 müezzin, kayyım, ferraş ve çerağidir. ${ }^{36}$ Benzer bir uygulama Pertevniyal Valide Sultan'ın Ramazan ayında mektep çalışanlarına verdiği ekstra ücretlerde de görülmektedir (Çiçek, 2018: 91; Yıldız, 2016: 59).

\section{Sonuç}

Ramazan İslam tarihi boyunca bir çeşit arınma ve maneviyatı yükseltme ayı olarak algılanmıştır. Osmanlı Devleti'nde de Ramazan ayı coşkulu bir şekilde yaşanmış, camiler her zamankinden daha fazla ibadetin yapıldığı, ehil kâri'ler tarafindan Kur'ân-ı Kerim'in okunduğu, geleneğimizde yer bulmuş olan temcid vb. özel uygulama ve duaların icra edildiği mekânlar haline gelmiştir.

Bu ayda ihtiyaç sahipleri diğer zamanlardan daha fazla hatırlanmış, kimsenin aç ve açıkta kalmamasına özel gösterilmiştir. Böyle bir sosyal ortamın yaşandığı esnada aynı toplumun öncü konumunda bulunması beklenen Osmanlı hanedan mensubu hanımlar da tesis ettikleri vakıflarında Ramazan ayına özel bir önem ve değer atfetmişlerdir. Bunlardan bazıları oruç tutan Müslümanların oruçlarını açmaları için iftariyelik hazırlanmak üzere külliyetli miktarlar tahsis ederken, diğer bir kısmı da kurdukları imaretlerinde her daim verilen yemeğin miktar ve kalitesinin arttırımasını sağlamışlardır. Yine sıcak yaz Ramazanlarında soğuk sularla serinlemelerini arzu etmişlerdir.

Bazı saray mensubu hanımlar ise çocukların Ramazan'ın bereketini küçük yaştan algılamalarını sağlamak ve özellikle de yetimleri sevindirmek üzere Ramazan'da onlara elbise alınmasını istemişlerdir. Vakfin düzgün bir şekilde işletilebilmesinin vakıf çalışanlarının gayretinden geçtiğinin farkında olarak baklava akçesi ya da başka adlarla vakıf mensuplarına teşvik için verecekleri ikramiyeleri bereketine uygun düşecek şekilde Ramazan ayında dağıtmışlardır.

Sonuç olarak Ramazan ayının toplumun her kesimine sirayet eden coşku ve bereketine hanedan mensubu hanımlar da kurdukları vakıflarda yaptıkları düzenlemelerle destek vermişler ve bu hususta topluma örnek olmuşlardır. 


\section{Kaynaklar}

\section{Arşiv Kaynakları}

Fatih Millet Kütüphanesi, Ali Emirî, Arapça Yazmalar, nu: 4469.

Vakıflar Genel Müdürlüğü Arşivi (VGMA), D. 1431, K. 98, 1/1; VGMA, D. 1452, K. 177, s.

131a-132a.;VGMA, D. 1452, K. 177, s. 144b.;VGMA, D. 1452, K. 177, s. 151a, 151b; VGMA, D. 1453, K.

176, s. 24a; VGMA, D. 1640, 27/6, s. 33; VGMA, D. 1640, 27/6, s. 39; VGMA, D. 1642, 22/3; VGMA, D.

576, 31/15; VGMA, D. 590, 207/181; VGMA, D. 590, 207/181; VGMA, D. 608/2, 222, 177; VGMA, D.

608/2, 235, 178; VGMA, D. 744, 112/29.

\section{Araştrrma ve incelemeler}

Akbulut, Müşfika (2003). Üsküdar Yeni Camii ve Külliyesi. Marmara Üniversitesi Sosyal Bilimler Enstitüsü (Yayınlanmamış Yüksek Lisans Tezi).

Akyıldız, Ali (2001). "Kadınefendi”. Diyanet Vakfi İslam Ansiklopedisi, (24), 94-96.

(2012). "Valide Sultan". Diyanet Vakfi Islam Ansiklopedisi, (42), 494-499.

Argıt, Betül İpşirli (2014). Rabia Gülnuş Emetullah Sultan 1640-1715. İstanbul: Kitap Yayınevi.

Ateş, İbrahim, (1982). "Hayrî ve Sosyal Hizmetler Açısından Vakıflar", Vakıflar Dergisi, (15), 55-88.

Bezci, Gül, (2018). Osmanlı Toplumunda Ramazan Kültürü, Dumlupınar Üniversitesi Sosyal Bilimler

Enstitüsü, (Yayınlanmamış Yüksek Lisans Tezi).

Bozkurt, Nebi (2001) “Kandil”. Diyanet Vakfi İlam Ansiklopedisi, (24), 299-300.

(2003) "Mahya". Diyanet Vakfi İslam Ansiklopedisi, (27), 396-398.

Çiçek, İlknur, (2018). Pertevniyal Valide Sultan'ın Hayat, Hayır İşleri ve Aksaray'daki Külliyesi. Süleyman Demirel Üniversitesi Sosyal Bilimler Enstitüsü, (Yayınlanmamış Yüksek Lisans Tezi).

Demir, Yasemin (2019). Muhasebe Defterlerine Göre (1279-1289/1862-1872) Pertevniyâl Valide Sultan Vakfi. Marmara Üniversitesi Sosyal Bilimler Enstitüsü, (Yayınlanmamış Yüksek Lisans Tezi).

Dikeçligil, Özlem (2015). Osmanlı İmparatorluğunda Miskinler: Üsküdar Miskinler Tekkesi'nin Sosyal ve İktisadi Etkileri. İstanbul Üniversitesi Sosyal Bilimler Enstitüsü, (Yayınlanmamış Yüksek Lisans Tezi).

İbnü'I-Esir (1994). Üsdü'I-gabe fi Marifeti's-sahabe. C.I, Beyrut: Darü'I-Kütübi'I-ilmiyye.

ipşirli, Mehmet, (2007 ). "Paşmaklık”. Diyanet Vakfi İlam Ansiklopedisi, (34), 186-187.

Kala, Eyüp Sabri -idris Akarçeşme (2019). Mihrişah Sultan Vakfi. Ankara: Vakıflar Genel Müdürlüğü Yayınları.

Karaca, Filiz (1997). “Hanım Sultan”. Diyanet Vakfi Islam Ansiklopedisi, (16), 28-29.

Kartal, Şehri (2012). Haseki Hürrem Sultan Yapıları. İstanbul Teknik Üniversitesi Fen Bilimleri Enstitüsü, (Yayınlanmamış Yüksek Lisans Tezi).

Köksal, Asım (1981). İslam Tarihi. C. I-XI. İstanbul: Şamil Yayınevi.

Maydaer, Saadet (2007). "Seyyid Hüseyin Erzincani Vakfi". Uludağ Üniversitesi Illahiyat Fakültesi Dergisi, (16/2), 287-308.

(2009). Osmanlı Klasik Döneminde Bursa'da Bir Semt: Hisar. Bursa: Emin Yay.

Nikiforuk, Andrew (2013). Mahşerin Dördüncü Atıısı Salgın ve Bulaşıcı Hastalıklar Tarihi. İstanbul: Iletişim yay.

Orhonlu, Cengiz ve Nejat Göyünç (1997). "Has". Diyanet Vakfi İlam Ansiklopedisi, (16), 268-270.

Öcalan, Hasan Basri, Sezai Sevim ve Doğan Yavaş (2013). Bursa Vakfiyeleri I. İstanbul: Bursa Büyükşehir Belediyesi yay.

Özcan, Abdülkadir. (1980-81). “Fatih'in Teşkilat Kanunnâmesi ve Nizam-ı Âlem İçin Kardeş Katli Meselesi". İstanbul Üniversitesi Edebiyat Fakültesi Tarih Dergisi, (33), 7-56. 
Özel, Ahmet (1995). “Emeviyye Camii”(Sosyal Hayattaki Yeri). Diyanet Vakfi Islam Ansiklopedisi, (11), 108-111.

Özgüleş, Muzaffer (2013). Gülnuş Emetullah Sultan’ın İmar Faaliyetleri. İstanbul Teknik Üniversitesi Fen Bilimleri Enstitüsü, (Yayınlanmamış Doktora Tezi).

Pantrk, Ramazan (2014). Atik Valide Sultan Külliyesi (1686-1727). Hacettepe Üniversitesi Sosyal Bilimler Enstitüsü (Yayınlanmamış Yüksek Lisans Tezi).

Peirce, Leslie P. (2002). Harem-i Hümayun: Osmanlı Imparatorluğunda Hükümranlık ve Kadınlar. İstanbul: Tarih Vakfi Yurt Yay.

Sabırlı, Tijen (2012). Vakfiyesi ve Muhasebe Kayıtları Işı̆̆ında Nurbanu Atik Valide Sultan Vakfi. İstanbul Üniversitesi Sosyal Bilimler Enstitüsü, (Yayınlanmamış Yüksek Lisans Tezi).

(2017). Nurbanu Atik Valide Sultan Vakf'nın Sosyal ve Ekonomik Açıdan İncelenmesi

1582-1826. İstanbul Üniversitesi Sosyal Bilimler Enstitüsü, (Yayınlanmamış Doktora Tezi).

Sevim, Sezai ve Hasan Basri Öcalan (2010). Osmanlı Kuruluş Dönemi Bursa Vakfiyeleri. İstanbul: Bursa Osmangazi Belediyesi yay.

Seyhun, Oğuleke (2019). Pertevniyal Valide Sultan'ın Vakıfları ve Mahmudiye Merkez Rüşdiyesi. Mimar Sinan Güzel Sanatlar Üniversitesi Sosyal Bilimler Enstitüsü, (Yayınlanmamış Yüksek Lisans Tezi).

Singer, Amy (2004). Osmanlı'da Hayırseverlik Kudüs'te Bir Haseki Sultan Imareti. İstanbul: Tarih Vakfi Yurt Yayınları.

Şafak, Nurdan (2017). Hayırsever Bir Osmanlı Valide Sultanı: Hatice Turhan Sultan ve Vakfiyesi. İstanbul: Fatih Sultan Mehmed Vakıf Üniversitesi Yay.

Şemseddin Sami, (1996). Kâmûs-ı Türkî. İstanbul: Çağrı yay.

Şirvanî, Muhammed b. Mahmud (2005). 15. Yy. Osmanlı Mutfağı. yay. haz. Mustafa Argunşah-Müjgan Çakır, İstanbul: Gökkubbe yay.

Terzi, Arzu (2018). Bezmialem Valide Sultan. İstanbul: Bezmialem Vakıf Üniversitesi Yay.

Uluçay, M. Çağatay (2001). Padişahların Kadınları ve Kızları. Ankara: TTK yay.

(2011). Harem. İstanbul: Ötüken yay.

Uzunçarşılı, İsmail Hakkı (1988). Osmanlı Devleti'nin Saray Teşkilatı. Ankara: TTK yay.

Üçok, Coşkun (1944). “Osmanlı Devlet Teşkilatında Tımarlar”. Ankara Üniversitesi Hukuk Fakültesi Dergisi, (1/4), 525-551.

Ünsal, Gizem, (2011). Ramazan'da Söylenen Mani Fasıllarını İçeren Eserlerin Folklorik Bakımdan Değerlendirilmesi. İstanbul Üniversitesi, Sosyal Blimler Enstitüsü (Yayınlanmamış Yüksek Lisans Tezi).

Yediyıldız, Bahaeddin (1982). "Vakıf Müessesesinin XVIII. Asır Türk Toplumundaki Rolü”, Vakıflar Dergisi, (14), 1-27.

Yerasimos, Marianna, (2011). Evliya Çelebi Seyahatnamesi'nde Yemek Kültürü. İstanbul: Kitap Yayınevi. Yıldırım, Nuran (2005). “Miskinler Tekkesi”. Diyanet Vakfi Islam Ansiklopedisi, (30), 185-186.

Yıldız, Emine (2016). Pertevniyal Valide Sultan Vakıflarının Sosyal ve Ekonomik Yönleri. Marmara Üniversitesi Sosyal Bilimler Enstitüsü (Yayınlanmamış Yüksek Lisans Tezi).

Yılmazörnek, Bekir (2010). Üsküdar Mihrimah Sultan Külliyesi. İstanbul Üniversitesi Sosyal Bilimler Enstitüsü (Yayınlanmamış Yüksek Lisans Tezi).

Zülfikar, F. Cangüzel (1989). Mihrimah Sultan'ın Vakıflar Genel Müdürlüğü Arşivinde Bulunan Vakfiyelerinin Değerlendirilmesi. Ankara Üniversitesi Sosyal Bilimler Enstitüsü, (Yayınlanmamış Yüksek Lisans Tezi). 